https://doi.org/10.32405/2522-9931-2021-18(47)-181-198

UDK 336.14.05

Nadiia Kovalenko,

PhD of Pedagogic Sciences, associated professor, associate professor at the department of management and economic

Flight Academy of National Aviation University.

Kropyvnytskyi, Ukraine.

iD https://orcid.org/0000-0002-1651-9750

nadinkovalenko508@gmail.com

Tetiana Doroshenko,

PhD of Pedagogic Sciences, associate professor at the department

of management and economic

Flight Academy of National Aviation University.

Kropyvnytskyi, Ukraine.

https://orcid.org/0000-0002-9968-9201

tat-doroshenko@ukr.net

Oksana Ursol,

PhD of Pedagogic Sciences, associate professor at the department of

Professional Education and Social-Humanitarian

Sciences Department, Flight Academy

of National Aviation University.

Kropyvnytskyi, Ukraine.

https://orcid.org/0000-0002-2819-0622

ursol7@ukr.net

\title{
EMOTIONAL INTELLIGENCE AS AN ELEMENT OF AIRLINE CORPORATE SOCIAL RESPONSIBILITY MANAGEMENT
}

\begin{abstract}
The study is devoted to the study of emotional intelligence as a basis for the formation of corporate culture of socially responsible enterprise. It is established that emotional intelligence can provide significant development of employees, increase their efficiency and competitiveness, ensure the growth of enterprise performance. Certainly, the development of emotional intelligence of enterprise personnel has become one of the most pressing problems of our time, which is why there is a need to consider this issue. All over the world, more and more attention is being paid to the workforce, ensuring its growth and development within the organization, because it will be the key to successful and efficient operation of the enterprise. The urgency of the topic is due to the fact that in Ukraine the emotional components of human resources are greatly underestimated, and as a result there is a mass
\end{abstract}


exodus of highly qualified specialists abroad, the collapse of many research and production teams and, finally, weakening the country's competitive position in the world labor market. It is specified that the meaning of the development of corporate culture on the basis of emotional intelligence is to build constructive relationships and succeed in business socialization. The analysis of the effectiveness of the use of emotional intelligence as the basis of corporate culture was conducted on a real object - the international airline «URGA». The model of development of emotional intelligence as an element of formation of corporate culture and maintenance of corporate social responsibility in the airline is developed and presented. The program of development of emotional intelligence which consists 3 modules, separately for each level of employees of the airline is presented. The effectiveness of the program for the development of emotional intelligence as an element of forming the corporate culture of the airline by improving both financial, economic and social performance.

Keywords: airline; emotional intelligence; corporate culture; personnel; corporate social responsibility of the enterprise.

\section{INTRODUCTION / ВCTУП}

Formulation of the problem. The development of emotional intelligence as the basis for the formation of corporate culture of the enterprise has become one of the most pressing problems of our time, which is why there is a need to study this topic. All over the world there is an emphasis on social responsibility of business, namely the workforce, ensuring its growth and development within the organization, because it will be the key to successful and efficient operation of the enterprise.

The urgency of the topic is due to the fact that in Ukraine the emotional components of human resources are greatly underestimated, and as a result there is a mass exodus of highly qualified specialists abroad, the collapse of many research and production teams and, finally, weakening the country's competitive position in the world labor market. However, the study of emotional intelligence as an element of the formation of corporate culture of socially responsible enterprise, are sporadic, and as a holistic study is not presented, respectively, this problem is relevant and needs more in-depth study. Despite numerous studies, there is no single approach to the methodology of evaluation and formation of emotional intelligence as an element of corporate culture of the enterprise, which is an additional problem for the effective implementation of socially responsible business. 
Given the challenge of practice, in order to practically identify problems in the formation of corporate culture, taking into account the elements of emotional intelligence of domestic enterprises, a scientific study was conducted on the basis of the International Joint-Stock Aviation Company «URGA», which is presented in the following sections. The aviation company was chosen not by chance, because the consideration of emotional intelligence as a factor in the formation of corporate culture by companies in the field of civil aviation in order to improve social responsibility is almost not studied.

Analysis of recent research and publications. Ukrainian and foreign scientists have made a significant contribution to the development of the theory and methodology of the development of emotional intelligence of staff and the development of corporate culture of socially responsible enterprises: K. Brown [1], M. Csikszentmihalyi [2], E. Nosenko [3], R. Bar-On [4], O. Bodnaruk [5], N. Kurovska [6] and others. However, the study of emotional intelligence as the basis for the formation of corporate culture of the enterprise, are sporadic, and as a holistic study is not presented, respectively, this problem is relevant and needs more in-depth study

\section{AIM AND TASKS / МЕTA TA ЗАВДАННЯ}

The main purpose of the article is to determine the theoretical and methodological recommendations for the development of emotional intelligence as an element of corporate culture and corporate social responsibility, development of regulations and practical recommendations, implementations aimed at improving the efficiency of civil aviation enterprises.

In accordance with this goal, the article sets the following objectives: to reveal the concepts and directions of development of emotional intelligence as an element of corporate social responsibility management of the airline; to analyze methodological approaches to the assessment of emotional intelligence as an element of corporate culture development; to analyze the effectiveness of the use of emotional intelligence as the basis of corporate culture conducted on a real object - the international airline «URGA»; to develop and present a model of development of emotional intelligence as an element of formation of corporate culture and ensuring corporate social responsibility in the airline.

\section{THE THEORETICAL BACKGROUNDS / TEOPETИЧHI ОСНОВИ ДОСЛІДЖЕННЯ}

At the present stage, the work of managers at different levels of management is becoming more informative, emotionally stressful and requires better management decisions. In addition, the complexity and dynamism of the 
external environment associated with increased competition, the effects of the global financial crisis, contributes to the emergence of internal organizational conflicts and high staff turnover. It is possible to resist significant influence of external and internal factors and at the same time to increase efficiency of administrative activity thanks to realization by the manager of the administrative potential, namely - emotional intelligence.

However, studies of emotional intelligence as an element of corporate social responsibility management of the airline are sporadic, and as a holistic study are not presented, respectively, this problem is relevant and needs more in-depth study. Despite numerous studies, there is no single approach to the methodology of assessment and formation of emotional intelligence as an element of corporate culture of a socially responsible civil aviation enterprise, which is an additional problem for effective business.

\section{RESEARCH METHODS / МЕTОДИ ДОСЛІДЖЕННЯ}

To solve this goal, a system of research methods was used, namely: analysis, observation, comparison, formalization, synthesis and systems approach. Using the method of analysis and observation were considered theoretical and methodological approaches to determining the emotional intelligence of staff, studied its impact on social performance of employees. Thanks to the methods of comparison and formalization, information about emotional intelligence as a basis for the formation of corporate culture of International Joint-Stock Aviation Company «URGA» was considered and structured. M. Hall's methods, SREIT and MSCEIT methods, V2.0 were used to assess the level of emotional intelligence of employees depending on the organizational level of International Joint-Stock Aviation Company «URGA» [7].

\section{RESEARCH RESULTS / РЕЗУЛЬТАТИ ДОСЛІДЖЕННЯ}

The work of a modern enterprise is determined not only by indicators of efficiency of production and sale of goods and services, but also a favorable emotional climate, motivation of workers to work and satisfaction with the results of their activities at the enterprise. Managers need to make decisions together with subordinates, delegate, provide feedback, motivate to achieve results, resolve conflicts. The effectiveness of these functions significantly depends on the level of development of emotional intelligence and corporate culture.

Thus, the ability of the leader to recognize and interpret the emotions that arise in the process of activity, use them to solve management problems in their relationship with the effectiveness of the organization as a whole determine the specifics of the problem field of emotional intelligence. 
In general, the definition of emotional intelligence can be represented as an integral property of the leader to recognize, understand, control, regulate their own emotions and the emotions of others and use these abilities to achieve professionally important goals. Over the past two decades, scientists have gained a new, deeper understanding of human behavior through the integration of sciences such as psychology (the study of human consciousness and behavior) and neurology (the study of brain anatomy and physiology). Doing business in accordance with the laws of neurobiology is much more difficult because it is necessary to take into account what others think, but at the same time the use of neuroleadership in the company helps to adjust staff motivation, change relationships between managers and subordinates.

In the field of management there are many examples of successful work of enterprises in which the work of personnel is effectively organized taking into account the theory of human behavior, brain structure and understanding of the basic principles of neuroleadership, where it is said By using brain research in practice, it will be possible to benefit not only for personal life, but also for business.

Corporate culture is a well-formed, stable system of norms and values, leading beliefs, principles and technologies of cooperation of social and labor relations entities in the life of the enterprise. It is manifested in the philosophy and ideology of management, the value orientations of management and employees, beliefs, expectations, norms of behavior. Corporate culture regulates the behavior of employees and makes it possible to predict its change in critical situations.

In the modern dimension, corporate culture becomes an important social institution, which determines a special type of sustainable regulation of social relations and various organizational forms of social regulation of the behavior of the subjects of social and labor relations.

It is determined that corporate culture and social responsibility as social phenomena and components of social relations are closely interrelated and have a mutual influence. The importance of corporate culture for the development of social responsibility in the enterprise is determined by certain circumstances: it provides employees with organizational identity, determines the internal idea of the enterprise and its main values, is an important source of stability in the enterprise; knowledge of the main principles of corporate culture of the enterprise helps new employees to quickly adapt and engage in effective work, correctly interpret the phenomena occurring in the enterprise, identifying in them all the most important and identify their role; corporate culture stimulates the consciousness and high responsibility of employees who perform the tasks assigned to them; corporate culture also nurtures the employer's social responsibility for employees, as well as employees' responsibility for the enterprise [8]. 
It is established that corporate culture permeates the entire system of corporate social responsibility: the bearers of corporate culture are the subjects of corporate social relations; regulation of social responsibility at the enterprise level is possible on the basis of corporate culture, so it is necessary to understand the clear relationship between the development of corporate social responsibility and corporate culture.

Every year, the issues of corporate social responsibility (corporate social responsibility) become more relevant for Ukraine, which is due to such groups of reasons [9]:

- firstly, enterprises are increasingly affected by the external environment and must respond accordingly to its challenges, in particular with regard to social guidelines;

- secondly, as labor is intellectualized, the role of human capital increases, employees' understanding of the concept of a decent job, fair remuneration for work, employment efficiency gradually changes, and their requirements for the companyemployer increase;

- thirdly, the dissemination of the principles of openness and transparency of companies makes available to employees and consumers any information about the functioning of the company, so the importance of a good image is growing;

- fourthly, the interest of potential investors in information about the company's competitiveness, concern for the environment, social responsibility is increasing.

Corporate social responsibility is the company's responsibility for the public utility of its activities to all people and organizations with which it interacts in the process of functioning, and to society as a whole. Social responsibility in general is a concept that encourages the interests of society to be taken into account, taking responsibility for the impact of one's activities on other people, communities and the environment in all aspects. Therefore, detailed definition of corporate social responsibility is formulated, covering the content, management, institutional components of this phenomenon: corporate social responsibility is a system of economic, social, environmental measures, as well as ethical norms and values of the company, which together ensure the public benefit of its activities. based on constant interaction with stakeholders (stakeholders) and aimed at long-term improvement of the company's image and business reputation, as well as the acquisition of competitive advantages and strategic stability of the business structure.

Therefore, any decision in the organization must be made taking into account the economic, social and environmental effects not only directly for the organization but also for society as a whole. It is important to note that a company that professes the principles of social responsibility, on the one hand, must comply with all statutory obligations and rules, and on the other - to assume additional obligations to 
implement various social programs both within the organization and and in the environment. Thus, in particular, the legally enshrined rights and obligations include:

- production of quality and safe goods and services;

- full payment of all types of taxes;

- payment of official wages to its employees without the formation of debts and deductions for their social security;

- compliance with antitrust laws;

- formation and development of "healthy" social and labor relations;

- compliance with legislation in the field of environmental protection and state requirements for environmentally friendly production;

- guaranteeing safety, labor protection of its employees, compliance with labor law;

- observance of general human rights enshrined in the Constitution of Ukraine.

The corporate culture of the enterprise, which takes into account the elements of emotional intelligence, creates a favorable socio-psychological climate at the enterprise; creates conditions for unlocking the potential of all employees; promotes productive and high-quality work through a fair system of motivation. The results of the assessment of emotional intelligence of the leaders of the International Joint-Stock Aviation Company «URGA», which are responsible for the formation of corporate culture, according to the testing of M. Hall, are presented in table 1 [8].

The results are analyzed on a scale of: levels of partial emotional intelligence (emotion management) in accordance with the sign of the results: 14 and more - high; 8-13 - average; 7 and less - low.

Table 1

Assessment of emotional intelligence of the management of the International Joint-Stock Aviation Company «URGA» by the method of M. Hall [9], [10]

\begin{tabular}{|l|c|c|}
\hline \multicolumn{1}{|c|}{ Supervisor (Head) } & $\begin{array}{c}\text { Assessment by the } \\
\text { level of partial } \\
\text { Emotional Intelligence }\end{array}$ & $\begin{array}{c}\text { Assessment of } \\
\text { integrative } \\
\text { level of corporatization }\end{array}$ \\
\hline $\begin{array}{l}\text { Head of the Personnel Training } \\
\text { and Retraining Department }\end{array}$ & 5 & 29 \\
\hline $\begin{array}{l}\text { Head of Crew and Commercial } \\
\text { Aviation Training Department }\end{array}$ & 7 & 40 \\
\hline $\begin{array}{l}\text { Head of Social Development } \\
\text { Departament }\end{array}$ & 4 & 38 \\
\hline
\end{tabular}


The integrative level of corporatization, taking into account the dominant sign, is determined by the following quantitative indicators: 70 and more - high; 40-69 - average; 39 and less - low.

Thus, the results show that the level of emotional intelligence of leaders ranges from low to medium (lower limit).

The scheme of introduction of values of social responsibility in corporate culture of the International Joint-Stock Aviation Company «URGA» unites 11 stages (fig. 1) [11]. The made conclusion is that that the heads of the operational level of "Personnel Service" the International Joint-Stock Aviation Company «URGA» according to this assessment need to develop a plan to increase emotional intelligence in order to increase the level of corporate culture according to the data obtained.

Referring to the results of the analysis, it is determined that managers and managers responsible for the formation of corporate culture at all levels from strategic to operational, need to develop and improve emotional intelligence, which is the basis for corporate culture of socially responsible organization. To ensure the successful operation of the airline, not only profit, but also the social effect of recognition, it is important to form a system of corporate values on the basis of social responsibility, implementation of social responsibility values in corporate culture and further orientation of all employees to social, environmental and moral and ethical norms [12]. The relationship between human values and the values of the airline in the system of social responsibility is determined by the fact that such phenomena as values, faith, culture, emotional intelligence, including the culture of responsibility, on the one hand, are formed by people (especially managers, but not only them), on the other hand, have a profound and very strong influence on personnel management, even if they are not described in documents, not published on posters, are not announced at meetings and official meetings.

They significantly affect the management's management and strategic decisions, the behavior of airline employees in everyday and especially in critical situations. The formation of the corporate culture of a socially responsible airline takes place in the context of solving two important problems: external adaptation and internal integration. The formation and development of emotional intelligence of the management of the International Joint-Stock Aviation Company «URGA» is today one of the main tasks of the airline's management. It is important to find a balance between efficient operations and productive work of workers, so that both parties are fully satisfied with the result and process [13]. The requirements of practice indicate that the priority for effective business and entrepreneurship is value-based neuromanagement. Accordingly, the airline's management needs to pay maximum attention to the use of emotional intelligence and the formation of neuroleader qualities of management in order to ensure and improve efficiency. 


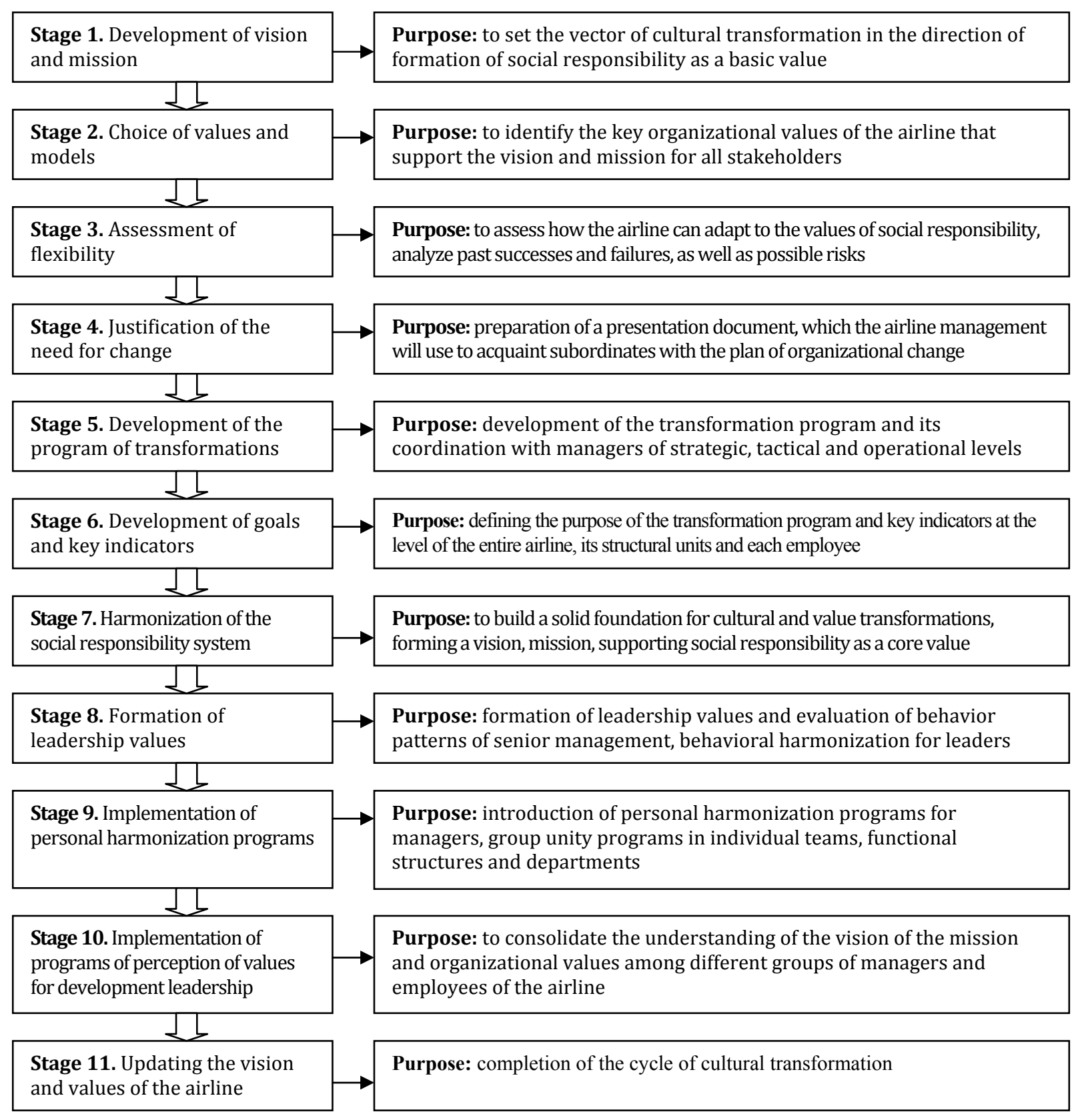

Source: compiled by the authors

Fig. 1 The scheme of introduction of values of social responsibility in corporate culture of the International Joint-Stock Aviation Company «URGA»

The responsibility for the actions of staff, in the absence of regulations, lies with the management of the airline, because it is the management with neuroleader qualities and emotional intelligence, should guide employees to follow, above all, the priorities of the International Joint-Stock Aviation Company «URGA», not personal. 
An alternative way to regulate business [14]:

- determine business priorities;

- determine the priorities of business units (departments, groups);

- determine the priorities of each employee;

- include the employee's priorities in the technical description of his business processes, leaving the necessary space for initiative and responsibility;

- to ensure the updating of priorities (if the circumstances imply a change of priorities, then first the priorities change and only then the decisions are made).

Business priorities should be common to all employees and special, taking into account the specifics of the business unit. Common priorities determine that employees not only know the principles to be followed, but also actually follow them not for extra pay and not out of a desire to avoid punishment, but only because they are deeply convinced that this is the only way to do it. focusing on emotional responsibility.

The level of control over the airline's dominant priorities will be much higher if the following principles are taken into account [15]:

- the principle of compliance with business objectives; People»;

- principle of personnel management - «Monolith of Like-minded

- the principle of explicit harmonization of values;

- the principle of comprehensive penetration and improvement;

- the principle of taking into account the interests of the five parties to the business (CEO / shareholders, customers, employees, partners, society).

In order to introduce corporate social management based on emotional intelligence in the International Joint-Stock Aviation Company «URGA», an algorithm has been developed according to which it is necessary to assess opportunities and what management values need to be taken into account. This algorithm will allow you to focus on the stages of making management decisions to implement and ensure the implementation of the project in the airline.

In the current economic situation, the solution of problematic issues related to emotions is extremely important. Communication between employees can affect their activities both positively and negatively, depending on many factors that unite emotional intelligence.

Research shows that high level of emotional intelligence is an indicator of mental health. Thus, it affects not only the indicator of success, but also the level of happiness.

In order to develop emotional intelligence it is necessary:

1 . Learn to recognize your own emotions. 
2. Interpret emotions.

3. Manage emotions.

However, it has been found that workers with low IQs cannot perform qualitative analysis and assessment of their own EI levels and do not know which pathway for neurodevelopment is effective.

Therefore, in order to increase the level of EI as an element of corporate culture of the International Joint-Stock Aviation Company «URGA», it is proposed to apply to the International Center "Creative Consulting Technologies" for professional development of a program for the development of emotional intelligence for airline employees.

Presented is a consulting company established in 2009 to implement the global mission of developing the theme of Emotional Intelligence (EI) and the introduction of practical methodology and modern digital solutions in business practice in Eastern Europe.

The consulting agency offers a program for the development of emotional intelligence and neuroleader qualities of the management staff of the International Joint-Stock Aviation Company «URGA», which includes 3 separate paths for managers of different levels.

The development program consists 3 modules, separately for each level of airline managers [10]:

1. Trainings on the development of emotional intelligence for the top management of the strategic level of the International Joint-Stock Aviation Company «URGA»: General Director, Vice President of Personnel, Head of the Department of Flight Operations of the International Joint-Stock Aviation Company «URGA». 2-day intensive training for the development of emotional intelligence and neuroleader qualities.

2. For tactical leaders, an online video course "School EQ" is offered. The cost of the course is 7,000 UAH.

3. For operational managers, it is proposed to install a mobile application «Leader's Psychology». The mobile application «Leader's Psychology» is a reliable assistant in solving psychological problems and the development of emotional intelligence and neuroleader qualities, it was developed by practical psychologists on the basis of modern research of emotional intelligence in integration with management.

According to the Robert Half Institute for Neuroscience, according to statistics from the International Center for Creative Consulting Technologies, it is established that measures to develop EI and neuroleader qualities of management staff improve financial and economic performance, which reflects the effectiveness of management decisions, and exactly: 
- profitability will increase by $45 \%$;

- labor productivity will increase by $2-3 \%$;

- net profit will increase by $15-20 \%$;

- reduction of staff turnover to 0 .

Thus, the practice of scientists in the field of neuroscience proves that the implementation of measures to improve the effectiveness of emotional intelligence as an element of corporate culture will have a positive impact not only on the management staff of the International Joint-Stock Aviation Company «URGA», but also improve financial, economic and social performance. namely: profitability will increase from $1.5 \%$ to $2.2 \%$, to $46.6 \%$; labor productivity will increase from 97.2 passengers / person up to 99.2 pass / person, to 2.1\%; net profit will increase by an average of $15.7 \%$ from UAH 2503,000 up to UAH $2,897,000$; staff turnover will be reduced to 0 , and in the next few years it is planned to attract more experienced and qualified managers.

Thus, the study concluded that increasing the efficiency of emotional intelligence as an element of corporate culture of the International Joint-Stock Aviation Company «URGA» will, under the program of the International Center "Creative Consulting Technologies», get an economic effect in the amount of 394,000 UAH for a year.

\section{CONCLUSIONS AND PROSPECTS FOR FURTHER RESEARCH / ВИСНОВКИ ТА ПЕРСПЕКТИВИ ПОДАЛЬШИХ ДОСЛІДЖЕНЬ}

It is determined that the development of emotional intelligence of enterprise personnel has become one of the most pressing problems of our time, which is why there is a need to consider this issue. The ability of the leader to recognize and interpret the emotions that arise in the process of activity, use them to solve management problems in their relationship with the effectiveness of the organization as a whole determine the specifics of the problem field of the concept of emotional intelligence.

It is established that the development of emotional intelligence of the staff of enterprises has become one of the most pressing problems of our time, which is why there is a need to consider this issue. Specifically, corporate culture and social responsibility as social phenomena and components of social relations are closely interrelated and have a mutual influence. Of course, the corporate culture of the enterprise, which takes into account the elements of emotional intelligence, creates a favorable socio-psychological climate in the enterprise; creates conditions for unlocking the potential of all employees; promotes productive and high-quality work through a fair system of motivation. The results obtained for managers of various levels of the International Joint-Stock 
Aviation Company «URGA» prove that it is necessary to pay attention to the development of their emotional intelligence in order to increase the effectiveness of socially responsible management and improve social and financial and economic performance of the airline.

In order to increase the level of emotional intelligence of the airline's management, it is proposed to apply to the International Center «Creative Consulting Technologies», which includes 3 separate paths for managers at different levels, as well as a model of emotional intelligence and neuroleader amounted to 78,400 $\mathrm{UAH}$. The implementation of the program will improve the financial and economic results of the airline, namely: profitability will increase from $1.5 \%$ to $2.2 \%$, to $46.6 \%$; labor productivity will increase from 97.2 passengers / person up to 99.2 pass / person, to 2.1\%; net profit will increase by an average of $15.7 \%$ from UAH 2503,000. up to UAH 2,897,000; staff turnover will be reduced to 0 , the economic effect of the program is $394,000 \mathrm{UAH}$ for a year.

Prospects for further research. Despite the demand of practice, the identification of problems in the formation of corporate culture, taking into account the elements of emotional intelligence of domestic aviation companies is quite slow. The principles and methods of management of corporate socially responsible civil aviation enterprises of Ukraine taking into account emotional intelligence remain unexplored.

\section{REFERENCES (TRANSLATED AND TRANSLITERATED) / СПИCOK ВИКОРИСТАНИХ ДЖЕРЕЛ}

[1] K. W. Brown, «The Benefits of Being Present: Mindfulness and Its Role in Psychological Well-Being», Journal of Personality and Social Psychology, Vol. 84, N 4, pp. 822-848, 2019.

[2] M. Csikszentmihalyi, "Introduction», in A Life Worth Living: Contributions to Positive Psychology. NY: Oxford University Press, 2021, pp. 3-14.

[3] Е.Л. Носенко, Емоційний інтелект: концептуалізація феномену, основні функції. Київ, Україна: Вища шк., 2020.

[4] R. Bar-On. Bar-On Emotional Quatient Inventory (Eq-i). Technical manual. Toronto, Canada: Multi-Health Systems, 2018.

[5] О. В.Боднарук, «Європейський досвід державного регулювання корпоративної соціальної відповідальності», Менеджер, № 2, с. 41-48, $2021 . \quad$ [Електронний Доступно: http://nbuv.gov.ua/UJRN/Nzhm 201627

ресурс].

[6] Н. О. Куровська, І. А. Оліфір, «Соціальна відповідальність бізнесу в умовах децентралізації», Вісник ЖНАЕУ, Т. 2, № 1(59), с. 68-75, 2017. 
[7] J. Mayer, «Emotional intelligence as a standard intelligence», Psychological Inquiry, 15, pp. 197-215, 2019.

[8] Т. В. Маматова, «Міжнародні стандарти корпоративної соціальної відповідальності: механізм адаптації для органів державного контролю України», Державне управління та місцеве самоврядування, Вип. 1(4), с. 109-120, 2020.

[9] Н. А. Супрун, «Корпоративна соціальна відповідальність як чинник соціального залучення (в контексті цілей стратегії "Europe-2020")», Український соціум, № 2, с. 163-176, 2021. [Електронний ресурс]. Доступно: http://nbuv.gov.ua/UJRN/Usoc 2013214

[10] N. Kovalenko, V. Stennikova, «Neuroleadership as a new direction in the aviation field», на IX Міжнар. наук.-практ. конф. Управління високошвидкісними рухомими об'єктами та професійна підготовка операторів складних систем. Кропивницький, 2020, с. 205-207.

[11] Авиакомпанія «УРГА»: офіційний сайт. [Електронний ресурс]. Доступно: https://urga.com.ua/

[12] A. B. Carroll, «Corporate social responsibility: Evolution of definitional construct», Business and Society, № 38(3), pp. 268-295, 2021.

[13] PR: Cooperatives recognised in EU's future on collaborative economy. [Online]. Available: https://coopseurope.coop/resources/news/prcooperativesrecognised-eusfuture-collaborative-economy

[14] Міжнародний інститут розвитку емоційного інтелекту: офіційний сайт. [Електронний ресурс].

Доступно: https://ring.org.ua/edr/uk/company/43549724.

[15] M. Zeidner, What we know about Emotional Intelligence. How it Affects Learning, Work, Relationships and our Mental Health. Massachusetts, USA: Massachusets, Institute of Technology, 2020.

\title{
ЕМОЦІЙНИЙ ІНТЕЛЕКТ ЯК ЕЛЕМЕНТ УПРАВЛІННЯ КОРПОРАТИВНОЮ СОЦІАЛЬНОЮ ВІДПОВІДАЛЬНІСТЮ АВІАКОМПАНІЇ
}

\author{
Коваленко Надія Олегівна, \\ кандидат педагогічних наук, доцент, \\ доцент кафедри менеджменту та економіки \\ Льотної академії Національного авіаційного університету. \\ Кропивницький, Україна. \\ iD https://orcid.org/0000-0002-1651-9750 \\ nadinkovalenko508@gmail.com
}




\section{Дорошенко Тетяна Миколаївна,}

кандидат педагогічних наук,

доцент кафедри менеджменту та економіки

Льотної академії Національного авіаційного університету.

Кропивницький, Україна.

ID https://orcid.org/0000-0002-9968-9201

tat-doroshenko@ukr.net

\section{Урсол Оксана Володимирівна,}

кандидат педагогічних наук,

доцент кафедри професійної педагогіки

та соціально-гуманітарних наук

Льотної академії Національного авіаційного університету.

Кропивницький, Україна.

https://orcid.org/0000-0002-2819-0622

ursol7@ukr.net

Анотація. Дослідження присвячено вивченню емоційного інтелекту як основи формування корпоративної культури соціально відповідального підприємства. Встановлено, що емоційний інтелект може забезпечити значний розвиток працівників, підвищити їх працездатність та конкурентоспроможність, забезпечити зростання показників діяльності підприємства. Визначено, розвиток емоційного інтелекту персоналу підприємств став однією з найбільш актуальних проблем сучасності, саме тому існує необхідність розгляду даного питання. У всьому світі починають все більше приділяти увагу саме трудовому колективу, забезпеченню його росту та розвитку всередині організації, адже це стане запорукою успішного та ефективного функціонування підприємства. Актуальність теми зумовлена тим, що в Україні емоційні складові людських ресурсів сильно недооцінюються, і як наслідок відбувається масовий відтік висококваліфікованих спеціалістів за кордон, розпад багатьох наукових та виробничих колективів i, нарешті, послаблення конкурентних позицій держави на світовому ринку праці. Конкретизовано, що сенс розвитку корпоративної культури на базі емоційного інтелекту полягає в тому, щоб вибудовувати конструктивні відносини і досягати успіху в соціалізації бізнесу. Аналіз ефективності використання емоційного інтелекту як основі корпоративної культури проведено на реальному об'єкті - міжнародній авіакомпанії «УРГА». Розроблена й представлена модель розвитку емоційного інтелекту як елементу формування корпоративної культури та забезпечення корпоративної соціальної відповідальності в авіакомпанії. Представлена програма розвитку 
емоційного інтелекту, яка складається із 3 модулів, окремо для кожного рівня працівників авіакомпанії. Доведена ефективність програми розвитку емоційного інтелекту як елементу формування корпоративної культури авіакомпанії шляхом покращення як фінансово-економічних, так i соціальних показників діяльності.

Ключові слова: авіакомпанія; емоційний інтелект; корпоративна культура; персонал; корпоративна соціальна відповідальність підприємства.

\title{
ЭМОЦИОНАЛЬНЫЙ ИНТЕЛЛЕКТ КАК ЭЛЕМЕНТ УПРАВЛЕНИЯ КОРПОРАТИВНОЙ СОЦИАЛЬНОЙ ОТВЕТСТВЕННОСТЬЮ АВИАКОМПАНИИ
}

\author{
Коваленко Надежда Олеговна, \\ кандидат педагогических наук, доцент, \\ доцент кафедры менеджмента и экономики \\ Летной академии Национального авиационного университета. \\ Кропивницкий, Украина.
}

iD https://orcid.org/0000-0002-1651-9750 nadinkovalenko508@gmail.com

Дорошенко Татьяна Николаевна, кандидат педагогических наук, доцент кафедры менеджмента и экономики Летной академии Национального авиационного университета. Кропивницкий, Украина.

iD https://orcid.org/0000-0002-9968-9201 tat-doroshenko@ukr.net

\section{Урсол Оксана Владимировна,} кандидат педагогических наук, доцент кафедры профессиональной педагогики и социально-гуманитарных наук Летной академии Национального авиационного университета. Кропивницкий, Украина.

iD https://orcid.org/0000-0002-2819-0622 ursol7@ukr.net

Аннотация. Исследование посвящено изучению эмоционального интеллекта как основы формирования корпоративной культуры социально ответственного предприятия. Установлено, что эмоциональный интеллект может обеспечить значительное развитие работников, повысить их работоспособность и конкурентоспособность, рост показателей деятельности предприятия. Определено, что развитие 
эмоционального интеллекта персонала предприятий стало одной из наиболее актуальных проблем современности, именно поэтому существует необходимость рассмотрения данного вопроса. Во всем мире начинают все больше уделять внимание именно трудовому коллективу, обеспечению его роста и развития внутри организации, ведь это станет залогом успешного и эффективного функционирования предприятия. Актуальность темы обусловлена тем, что в Украине эмоциональные составляющие человеческих ресурсов сильно недооцениваются, и, как следствие, происходит массовый отток высококвалифицированных специалистов за границу, распад многих научных и производственных коллективов и, наконец, ослабление конкурентных позиций государства на мировом рынке труда. Конкретизировано, что смысл развития корпоративной культуры на базе эмоционального интеллекта состоит в том, чтобы выстраивать конструктивные отношения и добиваться успеха в социализации бизнеса. Анализ эффективности использования эмоционального интеллекта как основе корпоративной культуры проведен на реальном объекте - международной авиакомпании «УРГА». Разработана и представлена модель развития эмоционального интеллекта как элемента формирования корпоративной культуры и корпоративной социальной ответственности в авиакомпании. Представлена программа развития эмоционального интеллекта, состоящая из 3 модулей, отдельно для каждого уровня сотрудников авиакомпании. Доказана эффективность программы развития эмоционального интеллекта как элемента формирования корпоративной культуры авиакомпании посредством улучшения как финансово-экономических, так и социальных показателей деятельности.

Ключевые слова: авиакомпания; эмоциональный интеллект; корпоративная культура; персонал; корпоративная социальная ответственность компании.

\section{REFERENCES (TRANSLATED AND TRANSLITERATED)}

[1] K. W. Brown, «The Benefits of Being Present: Mindfulness and Its Role in Psychological Well-Being», Journal of Personality and Social Psychology, Vol. 84, N 4, pp. 822-848, 2019.

[2] M. Csikszentmihalyi, «Introduction», in A Life Worth Living: Contributions to Positive Psychology. NY: Oxford University Press, 2021, pp. 3-14.

[3] E. L. Nosenko, Emotsiinyi intelekt: kontseptualizatsiia fenomenu, osnovni funktsii. Kyiv, Ukraina: Vyshcha shk., 2020. 
[4] R. Bar-On. Bar-On Emotional Quatient Inventory (Eq-i). Technical manual. Toronto, Canada: Multi-Health Systems, 2018.

[5] O.V. Bodnaruk, «Ievropeiskyi dosvid derzhavnoho rehuliuvannia korporatyvnoi sotsialnoi vidpovidalnosti», Menedzher, № 2, s. 41-48, 2021. [Elektronnyi resurs]. Dostupno: http://nbuv.gov.ua/UJRN/Nzhm 201627

[6] N. O. Kurovska, I. A. Olifir, «Sotsialna vidpovidalnist biznesu v umovakh detsentralizatsii», Visnyk ZhNAEU, T. 2, № 1(59), s. 68-75, 2017.

[7] J. Mayer, «Emotional intelligence as a standard intelligence», Psychological Inquiry, 15, pp. 197-215, 2019.

[8] T. V. Mamatova, «Mizhnarodni standarty korporatyvnoi sotsialnoi vidpovidalnosti: mekhanizm adaptatsii dlia orhaniv derzhavnoho kontroliu Ukrainy», Derzhavne upravlinnia ta mistseve samovriaduvannia, Vyp. 1(4), s. 109-120, 2020.

[9] N. A. Suprun, «Korporatyvna sotsialna vidpovidalnist yak chynnyk sotsialnoho zaluchennia (v konteksti tsilei stratehii "Europe-2020")», Ukrainskyi sotsium, № 2, s. 163-176, 2021. [Elektronnyi resurs]. Dostupno: http://nbuv.gov.ua/UIRN/Usoc 2013214

[10] N. Kovalenko, V. Stennikova, «Neuroleadership as a new direction in the aviation field», na IX Mizhnar. nauk.-prakt. konf. Upravlinnia vysokoshvydkisnymy rukhomymy obiektamy ta profesiina pidhotovka operatoriv skladnykh system. Kropyvnytskyi, 2020, s. 205-207.

[11] Avyakompaniia «URHA»: ofitsiinyi sait. [Elektronnyi resurs]. Dostupno: https://urga.com.ua/

[12] A. B. Carroll, «Corporate social responsibility: Evolution of definitional construct», Business and Society, № 38(3), pp. 268-295, 2021.

[13] PR: Cooperatives recognised in EU's future on collaborative economy. [Online]. Available: https://coopseurope.coop/resources/news/prcooperativesrecognised-eusfuture-collaborative-economy

[14] Mizhnarodnyi instytut rozvytku emotsiinoho intelektu: ofitsiinyi sait. [Elektronnyi resurs].

Dostupno: https://ring.org.ua/edr/uk/company/43549724.

[15] M. Zeidner, What we know about Emotional Intelligence. How it Affects Learning, Work, Relationships and our Mental Health. Massachusetts, USA: Massachusets, Institute of Technology, 2020. 